\title{
DIGITAL CITY: CHICAGO AND SCHAUMBURG (USA) INFORMATION, SUSTAINABILITY INDICATORS AND PUBLIC SERVICES PROJECTS
}

\section{DIGITAL CIDADE: CHICAGO E SCHAUMBURG (EUA) INFORMAÇÕES, INDICADORES DE SUSTENTABILIDADE E PROJETOS DE SERVIÇOS PÚBLICOS}

\section{Denis Alcides Rezende}

Doutor em Engenharia de Produção pela Universidade Federal de Santa Catarina, UFSC, Brasil. Professor titular Pesquisador Permanente da Pontifícia Universidade Católica do Paraná (PUCPR) E-mail: denis.rezende@pucpr.br (Brasil) 


\title{
DIGITAL CITY: CHICAGO AND SCHAUMBURG (USA) INFORMATION, SUSTAINABILITY INDICATORS AND PUBLIC SERVICES PROJECTS
}

\begin{abstract}
Information, sustainability indicators and efficient public services are a permanent challenge for cities concerned with citizens' quality of life and effective local government. The objective of this study is to assess the digital city projects in Chicago and Schaumburg (USA), using information, sustainability indicators and public services offered to citizens by the website. The research methodology consisted of case studies covering city hall, municipal departments, and other local governmental entities. The analysis and results show similarity in the typologies of information, sustainability indicators and public services but also large discrepancies in amount of service provided. The conclusion demonstrates the importance of making digital city projects a municipal priority, mainly by having their projects among the USA top 10. It resulted in benefits for citizens through access to information, sustainability indicators and public services offered by the city and can contribute with the challenging issues of sustainability of cities, governments and citizens, as a form of participation in the planning and sustainability management in cities.
\end{abstract}

Keywords: Digital City Projects; City Information; Sustainability Indicator; Public Services; Public Participation. 


\section{DIGITAL CIDADE: CHICAGO E SCHAUMBURG (EUA) INFORMAÇÕES, INDICADORES DE SUSTENTABILIDADE E PROJETOS DE SERVIÇOS PÚBLICOS}

\section{RESUMO}

Informações, indicadores de sustentabilidade e serviços públicos eficientes são desafios permanentes para cidades preocupadas com a qualidade de vida dos cidadãos e com governo local efetivo. O objetivo deste estudo é avaliar os projetos digitais da cidade em Chicago e Schaumburg (EUA), utilizando informações, indicadores de sustentabilidade e serviços públicos oferecidos aos cidadãos pelo website. A metodologia de pesquisa enfatizou estudos de casos nas prefeituras, secretarias municipais e outras entidades governamentais locais. As análises e os resultados mostram semelhança nas tipologias de informações, indicadores de sustentabilidade e serviços públicos, mas também grandes discrepâncias na quantidade de serviços prestados. A conclusão demonstra a importância que fazer projetos de cidades digitais é uma prioridade municipal, principalmente por ter seus respectivos projetos entre os 10 melhores dos EUA. Isso resultou em benefícios para os cidadãos, por meio do acesso às informações, aos indicadores de sustentabilidade e aos serviços públicos oferecidos pelas cidades que podem contribuir com as questões desafiadoras da sustentabilidade das cidades, governos e cidadãos, como uma forma de participação no planejamento e na gestão das cidades.

Palavras-Chave: Projetos de Cidade Digital. Informações de Cidades. Serviços Públicos. Participação Pública. 


\section{INTRODUCTION}

Information, indicator and public services, along with information technology (IT), interact in many ways to affect the quality of life in cities and the effectiveness of egovernment models. The use of information and indicator to provide public services is a particularly large challenge for cities concerned with planning and development. Particularly for those interested in citizens' quality of life and effective municipal management. Such a challenge requires the involvement of the whole population of the city, whether they are workers, students, retired individuals, housewives, councilors or businessmen. Furthermore, the social, environmental, financial and political issues that cities constantly face mean that public managers are under pressure to adapt accordingly. At the same time, the participation of citizens in the affairs of a city is an inexorable requirement. One way of addressing these challenges is through collective information, indicator and public services at both the city hall and municipality level, where systematized information is a prerequisite for effective municipal organizational and management activities.

A digital city project can contributes to the improvement of public policies and government programs through the provision of information, indicator and public services to citizens. Information can be an important resource that adds value to municipal management, facilitating communication between the citizens and government to expand the credibility and trust, while promoting accountability, transparency, and democracy. With the use of information technology, it is possible to further integrate the citizen to the government.

For effective integration between citizen and government, it is necessary to discuss and plan in advance for information, indicator and public services. The planning of information, indicator and public services, like municipal strategic planning, is of unquestionable importance. Pressures for effectiveness can be minimized by the preparation and implementation of participative strategic planning in the cities, as it propitiates the collective engagement of the citizens with their wishes and also decentralizes and shares the local managers' decisions. Information, indicator and public services planning, like other municipal plans (e.g. Strategic Municipal Planning, Municipal Director Plan, Municipal Multi-Annual Plan, Governmental Plan and others) requires comprehensive practical exercises based on deep-seated theories. These exercises are related to dynamic intelligent daily activities of city halls and the management actions of the cities. Such activities have to be prepared in an integrated and structured way, where personalized and timely information 
are utilized for suitable and participative management of the cities. Evidently, these activities will be more profitable to the cities if they have effective participation of their citizens.

Many cities have problems with the inexistence or inadequacy of information, indicator and public services, which enhances the difficulties of municipal management. Compounding this is the fact that citizen participation is uneven, creating sub-optimal democracy and a lack of full contribution to urban, rural and regional development. It is emphasized by authors that researching the subject (Townsend, 2003; Firmino, 2004; Guerreiro, 2006; Mendes, Bottoli, and Breda, 2010; Duarte and Pires, 2011; England; Pelissero and Morgan, 2012; Rezende, 2012; Ekionea, Fillion, and Koffi, 2012; Flores and Rezende, 2013; Rezende et al, 2015).

The objective of this study is to assess the digital city projects in Chicago and Schaumburg (Illinois, USA) as a form of participation in the society's and cities. The project emphasized information, sustainability indicators and public services offered by website. Both projects covered city hall, municipal departments, and other municipal entities, such as schools, health centers and citizen-oriented municipal information offices.

Determined benefits for citizens through access to information, sustainability indicators and public services offered by the cities and some contributions for the challenging issues of sustainability of cities, governments and citizens, as a form of participation in the planning and sustainability management in cities.

The research question and the reason for that is due to structuring, storage and availability of information, indicator and public services, which surely do not happen overnight and require short, medium and long term actions.

The article is structured in chapters: introduction to the themes; literature review with concepts used in the research; research methodology and protocol; analysis of information, indicator, public services and digital city project; discussion and conclusion

\section{LITERATURE REVIEW}

In order to have the concepts debated and understood some pertinent legislations and culture must be taken into consideration. 


\section{Public Services}

Public service can be understood as any service provided by the government or by their delegates under state standards and controls to meet the essential needs of the community or secondary or simple convenience of the State. Examples of public services include: public education, the police, the public health, the public transportation, telecommunications, and others (Meirelles, 2013). Also, public services can be understood as goods or services provided by the public sector for its constituents. Public services can be directly provided through the government or through financing the private sector provision of such services. The social rationale behind public services is that there are certain services that should be provided to all citizens, regardless of income (as defined by the market) or social standing. The deconcentration and devolution of public services delivery from the national to local governments and citizens have recently been applauded for their ability to see quicker gains than with centralized public services systems (Gfldr, 2010).

Scholars and administrators of municipal governments generally agree on four essential goals of public services: efficiency, effectiveness, equity and responsiveness (England, Pelissero, and Morgan, 2012). Historically, the role of government in providing these services has led to a notion of government as bureaucratic, hierarchical and controlling. This relationship has led to calls from academia and the city to democratize the structure of public services and bring the citizen into the equation. This theory of "new public service" is defined as a structure where the citizen is at the center of the governance system and not on the outside (Denhardt and Denhardt, 2000).

The provision of goods and services are transferred from private to public when the private sector underprovides or when it is a necessity for the citizens to survive. If these services were left up to the market, the population would be affected and while there is no legal ruling on public service provision, they generally are popular within a country. Since most public services are paid for through the tax system, the citizens of those geographic areas have a vested interest in the types of services made available (Gruber, 2011). A more important picture in this system is the role of information based public services. Since traditionally, governments have not had to compete with other vendors in their service provisions, they have not had to be concerned with disseminating adequate information about such services (Skelcher, 1992). This trend, however, has reversed in recent years with greater calls for complete transparency and full information of services.

Revista de Gestão e Secretariado-GeSec, São Paulo, v. 7, n. 2, p 55-79,mai./ago.2016. 


\section{Information, Information Model, Information System}

The concept of information is any datum that creates consideration or warrants contemplation. As a sustainability indicator, the information can be understood as an entity with a meaningful value attributed or added to it and having a natural and logical sense and application for its users (Rezende, 2012). Information, to be useful for decision-making, should have the following characteristics or premises: concrete, not to have verbs, and to be different from documents, programs, and files. Information and its respective systems serve crucial roles in the administrations of municipalities, presenting themselves as a strategic resource to help plan and manage city halls and towns in an intelligent, competitive, participative manner. To ensure this strategic connotation to information, the organization usually goes through an evolving cycle in stages that include: initiation, contact, control, integration, data administration, and maturity (Nolan, 1993).

The information acculturation process in the city halls and towns can be simple and effective if both public managers and residents (clients or information users) are participative, aware and thoroughly engaged in the utilization of information technological resources. The strategic information supported by information technology may occur in an evolving way, where information systems can be classified in various manners (Rezende, 2012). Information has a highly significant value and can create greater power for those who own it, be it a person or a city. The information valorization process comprises certain logical phases and steps. At least three steps are fundamental to add value to information: understanding, selecting and using information. A badly prepared selection may cause major damages in the use of information (Weitzen, 1991).

In cities, the information and the knowledge of people can contribute to municipal management. Information can enhance the roles and benefits of government and the citizen in any geographic area (Ekionea, Fillion, and Koffi, 2012). Nowadays, the techno-social networks also allow citizen participation in municipal management, as a channel of communication, exchanging information as a citizen to government and from government to citizen (Flores and Rezende, 2013).

The information model describes nearly all the necessary pieces of information for municipal management (Rezende, 2012). Such pieces of information can be structured in levels or types, i.e., strategic, managerial and operational information. They can be distributed according to their respective organizational functions or public issues. The information model 
is comprised of: strategic pieces of information (in a macro-related way with the external and internal environment), tactic and managerial pieces of information (grouped and synthesized) and operational pieces of information (in detail or analytical). Finally, the information model may contain integrated information, such as: conventional (trivial), personalized and timely.

All information can be classified as personalized information, either being a natural or legal person or a differentiated product or service. It may also be regarding a single characteristic of a citizen. All information of unquestionable quality, however, can be named 'timely information' (Rezende, 2012).

An information system produces, as an output, data processing or resource transformation. For instance, information, can take the form of a computational resource of information (O'Brien and Marakas, 2011). Information systems within city government whose primary purpose is to aid administrators in their decision-making processes and whose focus must be addressed to efficient municipal services - will be able to significantly contribute solutions to many municipal problems; to the extent that they effectively generate timely and personalized information. They must be seen as strategic tools to determine differential factors for city hall (Rezende, 2012). These systems of human and technical components accept, store, process, produce and transmit information, and can be used in conjunction with: human engagement, methodologies and information technology (Heeks, 2001). These are the ways by which people and organizations assemble process, store, use and disseminate information in a reciprocal relationship (Ward and Peppard, 2002).

An information system can positively influence operational effectiveness, municipal strategies and administrations, while benefiting any non-governmental actor that interacts with the municipality (Stair, 2007). The information system benefits are widely reported and justified in the pertinent literature and articles. They are presented as instruments for generating solutions to municipal problems (Laudon and Laudon, 2011). To facilitate these solutions, the information systems should be integrated and have an interdependent relation with the sub-systems, leading to the information exchange. This integration comes in many forms, including: systemic vision, systemic approach, forest view, municipal gear, information synergy and harmonic set of organizational functions. This way, the information systems show themselves to be sub-systems or organizational functions, divided into: production or services; commercial or marketing; material or logistics, financial, juridicallegal, human resources and their respective modules (Rezende, 2012). Only through the integration of these sub-systems will it be possible to produce efficient public services.

Revista de Gestão e Secretariado-GeSec, São Paulo, v. 7, n. 2, p 55-79,mai./ago.2016. 
The levels of information and decisions within city government mimic the pattern-hierarchy existing in most organizations (organizational pyramid). These levels are known as: strategic, tactic and operational. The decision made in each level requires varying degrees of information and data aggregation. The various decision levels call upon different information from their resulting products, such as screens, reports, etc. There is not any rigid classification to what allows people and administrations to classify their systems in different ways. All in all, the information system can be utilized in operational, managerial and strategic levels (Stair, 2007; Laudon and Laudon, 2011). The main difference amongst information systems in these classifications lays in the way the information is presented to users.

The operational information system provides detailed information. The managerial information system makes grouped or synthesized information available. The strategic information system enables the comparison of internal and external information flows within city hall, and intercity, and eventually generates indicators and knowledge. Another way to classify information systems is the city hall scope. In summation, there are systems at personal, group (or departmental), organizational, and inter-organizational levels where the global systems of information are framed, involving municipal governments of a multitude of geographic locations (Kroenke, 2011).

\section{Information Technology and Electronic Government}

The utilization of information technology (IT) or information and communication technologies (ICT) can be conceptualized as computational and technological resources for data storage, generation and use of information. IT is based on the following components: hardware and its devices and peripherals; software and its resources; telecommunications systems; data and information management (Stair, 2007; Turban, Mclean, and Wetherbe, 1996; Rezende, 2012). It can also be defined as telecommunications and computing technologies that supply automatic means and information handling, encompassing tangible hardware and intangible software (Heeks, 2001) and telecommunications networks (Ward and Peppard, 2002). 


\section{Digital City}

A digital city can be defined as a city that collects and organizes digital information, provides public information for person to person interaction online (Ishida, 2004) and can be lived in by digital citizens, who are able to participate in an online society (Mossberger, 2008). As large cities become more fragmented physically, socially, and culturally, computer communications are seen to be a potentially integrative medium, tying the disparate fragments together into new threads of public discourse, in ways that few other media can manage (Aurigi and Graham, 1997). In this sense, the concepts of connectivity, accessibility and responsiveness must be covered (Duarte and Pires, 2011).

The concept of digital cities emphasizes the gathering and organization of digital information to streamline the public services process and provide citizen/resident interaction (Besselaar and Beckers, 2009). It creates a digital network environment, which interlinks advanced technological systems to public services, assets, brands, schools, non-profit organizations, enterprises, and micro and macro communities. This prototype makes information available in several patterns aiming to develop the information society's potential and transform the citizen into actor and protagonist of a virtual reality (Guerreiro, 2006).

The digital city is concerned about physical changes that are necessary to enable ICTs and to maximize the conceptual, cultural and urban impacts of technologies (Atkinson, 1997; Shiode, 2000). Cities require new elements for organization and reproduction of the urban area, providing the shrinking of distances through the use of ICTs (Firmino, 2004) or like cities in network (Batten, 1995; Townsend, 2003).

Science and technology become important for urban development (Townsend, 2003). The challenges of urban area go beyond geographic boundaries. Instead, virtual activities conducted in cyberspace and bring the possibility of "distance annulation" amongst the dwellers of a city, even if the distance annulation be just symbolic, as it is through some types of digital activities (Lefebvre, 1991). The city changes due to the advent of new communication technologies in a continuous move towards "de-territorization" of symbolic worlds and the break-up of frontiers between the ancient and modern, between local and global, between written and audiovisual culture, leading to fast urban modernization processes into the adequate environment for digital cities (Barbero, 1996). The exchange of telematics information help people emerge from the time-space confinement, traffic and other difficulties of physical places (Lévy, 1999). It does not come to replace the real city with the 
virtual one; rather, the focus is on the enlargement of access for the citizens to activities of collective intelligence and on the occupation of the cyberspace, as in the geographic city, fulfilling thoroughly the citizens' needs (Mendes, Bottoli, and Breda, 2010).

In the context of telecommunications, digital cities are also called "information highways", with a set of web applications, IP applications, services and equipment that provide citizens with a constantly present, ubiquitous, pervasive environment that not only is present everywhere at the same time but also spreads itself, infiltrates, penetrates and is spread. Digital cities, which are also known as, amongst other things, cybercities, virtual cities, electronic cities and intelligent cities, represent projections into the digital world (Lévy, 1999).

The strategic digital city can be understood as an application of information technology resources in municipal management and in the availability of information and services to residents. It is a far-reaching project that extends far beyond simply offering internet services to citizens through telecommunications conventional resources. It goes beyond inclusion of citizens into the world network of computers, and into such ample projects as information systems for municipal management and citizen utilization, public services for the community and municipal safety systems (Rezende, 2012). Brazilian government has been creating special programs to enhance and spread information technology and telecommunication infrastructure, disseminate access to the Internet, and stimulate webbased public services (Rezende et al, 2014; Rezende et al, 2015).

\section{Municipal Planning and Information Technology Alignment}

Municipal Information Planning is a project that formalizes the necessary information for city hall and town management and, as a result, plans the municipal information systems and their respective needs of information technology assets and of human resources (Rezende, 2012).

Information Technology Strategic Planning (ITSP) is a dynamic and interactive process to, strategically, tactically and operationally, structure the organizational information, information systems, the information technology (and their resources: hardware, software, telecommunications systems and data and information management), the people involved, and the required infra-structure. This process positively assists all decisions, actions and 
respective processes of the organization (Turban, Mclean, and Wetherbe, 1996; Lederer and Mahaney, 1996; Rezende, 2012).

The alignment between the ITSP and the municipal information planning is built from the vertical, horizontal, transversal, dynamic and synergetic relations of the municipal functions and the IT resources. Such alignment can promote the adjustment of strategic and operational suitability within the available technologies as a municipal management tool put together by quality concepts, productivity, effectiveness, continuity, competitive intelligence and municipal intelligence (Henderson and Venkatraman, 1993; Rezende, 2012).

\section{Literature Review Synthesis}

The concepts and approaches: public service; information, information model, information system; information technology and electronic government; digital city; municipal planning and information technology alignment; were the bases for determining the variables to research: communicability; content; functionality; public services; and citizen participation analyses.

\section{RESEARCH METHODOLOGY}

The research methodology employed here comprises an analytical approach of applied work to a circumstantial reality, emphasizing the inductive method enhanced by professional experience achieved by the authors-researchers, both in advising projects for city halls and in academic projects for master and doctoral classes. It partially takes exploratory research concepts regarding documental and bibliographic raising (Nachmias and Nachmias, 2006).

The methodology consisted of case studies obtained from city hall. It has put together other approaches explained by the eclecticism and integration of inseparable methods (Yin, 2008) which can be determined on the basis of convenience for accessibility (Gil, 1999, p. 104; Roesch, 1999, p. 118) and because the cities having their projects among the USA top 10.

The study sample consisted of two cities: Chicago and Schaumburg (Illinois, USA). Chicago has about 3 million inhabitants, and Schaumburg has a population of nearly 75, 000. Chicago has been ranked the fourth and the fifth best digital city project among all 
major U.S. cities in 2011 and 2010, respectively. Alternately, Schaumburg has a quite extensive digital component to its public services, most notably its custom written, service request system (Digital Communities, 2013).

The research question: how is possible to structure, store and make available information, indicator and public services for citizens and public managers?. In addition, can contribute to the citizen quality of life and with the public managers' effectiveness?

The research protocol includes the analysis of specific criteria of the information, indicator and public services offered by the websites of City Hall with these variables to research: communicability; content; functionality; public services; and citizen participation analyses.

The observation unit included both websites and interviews with the respective managers of digital city projects. For research implementation were used "interview scripts and questionnaires" for interviews.

The research was prepared from July 2013 until January 2014. In addition, revised and updated in February 2016.

\section{ANALYSIS OF INFORMATION, INDICATOR, PUBLIC SERVICES AND DIGITAL CITY PROJECT}

Chicago offers its citizens 281 public services and Schaumburg offers 19 public services, subsumed into 16 categories. Of these, the most important is the Customer Service Request, which allows users to type key words to access the services they need.

All public services share their respective information or indicator.

\section{Types of Information, Indicator and Public Services Offered}

The information, indicator and public services offered by Chicago are classified into the following types of 256 subjects or themes (Appendix 1). Noteworthy are also the sustainability indicators to society and cities.

Chicago has embraced digital governance in several ways ranging from nearly 1,000 open databases to the recent launch of their "Data Dictionary" which aims to enhance the usability and accessibility of its open data program. The "Chicago Tech Plan" outlines 28 current and future initiatives (by strategy) that together will help Chicago become the city Revista de Gestão e Secretariado-GeSec, São Paulo, v. 7, n. 2, p 55-79,mai./ago.2016. 
fueled by technology. While many of these initiatives will be City-led, private, public, and nonprofit leaders are encouraged to contribute to the success of many of these activities. Some of the 28 initiatives include broader rollout of high-speed broadband, the introduction of public displays for residents and tourists to gain access to real-time, hyperlocal data, increase public Wi-Fi access, and "provide a broad range of intellectual and financial resources to help residents and civic technologists use technology to improve urban life." With foundational strategies: Next-Generation Infrastructure; Every Communities a Smart Communities; Efficient, Effective, and Open Government; Civic Innovation; Technology Sector Growth.

Schaumburg's public services are simplified to a greater extent than Chicago's. As mentioned above, Schaumburg provides 19 public services subsumed into 16 categories of public services, with the most prominent being the customer service portal. At this time, could not find a comprehensive list of services provided. Schaumburg's IT department uses a strategic plan (monthly report posted online has a link to this plan) that is flexible and routinely updated. It serves as a template for the public to understand government structure and mission and not a blueprint for day-to-day operations. Schaumburg seeks to strive for overall excellence, not municipal excellence. The idea is to operate most effectively, and government website is the vehicle for all of the initiatives in public service. There is an emphasis on what is adequate for the municipality to operate, transparency and creating public accessibility of all public records

The overarching goal within Schaumburg's governance is to create the best service possible, not the best government service. Each component operates from an idea of being the most efficient and serving to their constituents. The Schaumburg public manager reiterates that all essential public services are offered to citizens by the website.

\section{Communicability Analyses}

As criteria in the research protocol, ccommunicability is defined as the social and human components of Information Communication Technologies and is situated in the social sphere of information systems. For our purposes of more localized interactions, we can look at the efforts to incorporate diverse cultural and linguistic populations within the geographic boundaries of our observation units (Duarte and Pires, 2011).

Chicago's efforts at communicability are exemplified in the amount of services that entail filings of grievances and assistances. Both of these themes show an effort on City Revista de Gestão e Secretariado-GeSec, São Paulo, v. 7, n. 2, p 55-79,mai./ago.2016. 
Hall to provide an arena for public discourse and participation in the allocation of city services. The former serves to provide a voice for populations that previously did not have one, specifically in the fields of police brutality and/or discriminatory housing policies. These areas of public service provide sites for the public to actively communicate with agencies and fellow citizens in efforts to enhance the functioning of government through the use of complete and full information, indicator and quality public services. Chicago has more public services in website and more experience in communicating with its citizens. The citizens are satisfied how to show the satisfaction reports researched.

Schaumburg can improve its communicability and efforts to incorporate diverse cultural and linguistic populations. Schaumburg public managers still are working on a more comprehensive communicability project. And trying to provide more public services to its citizens that are not yet fully satisfied, mainly in terms of "information, sustainability indicators and public services".

\section{Content Analyses}

Content is other criteria in the research protocol. An analysis of content can be understood as the breadth of public information and indicator available on the website, the level of horizontal integration between government agencies and an estimate of the amount of information and indicator available about the dealings of such agencies (Middleton, 2007).

In Chicago and Schaumburg, information and indicator regarding each of the governmental agencies is clearly established on the website, including sustainability indicators to society and cities; with user friendly links at most points. Notably, in the field of job services, the website provides links to local, state and national agencies, showing a profound integration of information and indicator across geographic boundaries. The level of public information and indicator listed on the website is quite extensive, ranging from how to pay for parking tickets to obtaining FOIA (freedom of information act) documents (see list of themes).

In both cities, the content of "information, sustainability indicators and public services" available on the website is enough. Especially on Chicago that have a more experience and extensive project.

Furthermore, while not specifically stated by Middleton (2007), the organization of the content on the website is admirable and enhances the ability of the citizen to access the Revista de Gestão e Secretariado-GeSec, São Paulo, v. 7, n. 2, p 55-79, mai./ago. 2016. 
information and indicator they are searching for with ease and speed. Frequency of updated information and indicator is also a primary concern of a content analysis for information, indicator and public services. In this respect, Chicago and Schaumburg show a great effort for accuracy of useful information, indicator and efficient public services, including the sustainability indicators to society.

\section{Functionality Analyses}

The concept of functionality, as other criteria in the research protocol, is best understood as how effectively a site/organization is designed in order to help the user navigate it. This is inclusive of how the services are organized and if there are summaries of the broader service structure. This indicator is the broadest in most evaluative lists and specific criterion can include readability, visual aesthetics ease of use and robustness of public services forms. As government services are intended for public use, broad accessibility is encouraged and must take into account disability access, and compatibility across advancements in ICT's (Middleton, 2007).

Overall functionality and interface of its cities services website is clearly organized and easy to navigate. Subsuming the various services and information items into broader themes, allows the user of all levels to easily find what they are looking for. At the same time, it enables the interested user to scan the various thematic components of the website in a clear and concise manner. Additionally, the style is consistent on all pages, with its recognizable multi-shaded blue background and orange text/banners, signaling to the user that you are still within the cities website.

Finally, it is worth noting that Chicago and Schaumburg employ numerous interactive components through 'Online Service' icons. These are essential as they turn the passive user into an active user and they are clearly demarcated with a computer icon and are joined with a legend on the right hand side of the page in clear view.

The number of access to the website (monthly over 10000 in average to Chicago and more than 1000 in average for Schaumburg) reiterates proper functionality to offering "information, sustainability indicators and public services". 


\section{Public Services Analyses}

Public services are other criteria in the research protocol. Service delivery can be best understood with a two level approach: citizens and business. Within each of these levels, we measure availability of payment and registration and application services; for the citizen we look at online recruitment and for the business online tendering (Middleton, 2007).

In Chicago, these two levels of public services are not clearly separated, but are subsumed into the broad services list (organized in themes from A to Z). Within the advertising (partnership) section, there is no present online component, however there are phone numbers and email addresses to contact for further information and indicator, including sustainability indicators to society. From the citizen perspective there are some online components of registration/application services (i.e. 'Inviting the Mayor to an event' can be applied for online) but other services simply provide registration applications that must be then printed/downloaded and emailed/faxed/mailed through the postal service. This can be seen as an area of improvement for the city services as enhanced technologies arise, as a means to increase efficiency and ease. Chicago offers more public services in website because has a formal project: "Chicago Tech Plan" with 28 current and future initiatives (by strategy).

Also in Schaumburg, these two levels of public services are not clearly separated and are often mixed in services for citizens and for business. Schaumburg has no specific and comprehensive IT Project to provide public services more adequate to its citizens. The public managers are developing a comprehensive plan that includes "information, sustainability indicators and public services".

\section{Citizen Participation Analyses}

Citizen (public) participation, as criteria in the research protocol, is vital to the digital city project as a complement to municipal management innovation; participation and innovation are needed to realize the full potentials of such projects (Rezende et al, 2014; Rezende et al, 2015). Additionally, in Holzer's study, the measurements used included: online civic engagement, internet based policy deliberation and citizen based performance measurements (Holzer et al, 2005).

Chicago employs a thematic section on policy agendas for the citizen to view. Within this category sits the Capital Improvement Program Advisory Committee, which was Revista de Gestão e Secretariado-GeSec, São Paulo, v. 7, n. 2, p 55-79,mai./ago.2016. 
created from Executive order 90-2, sections one through three: (1) vest the powers to the Office of Budget and Management to annually develop a Capital Improvement Program, and decide the location, revenue source and name of all capital improvement projects undertaken by the City of Chicago; (2) establishes public meetings to debate on a Draft of the Program; (3) creates a Capital Improvement Advisory Committee (CIAC) to serve as an advisory body for the purpose of reviewing and making recommendations on the Capital Improvement Program and process. While it can be said that the public forum component seen in section two can work to increase citizen participation, it does so in a physical setting, which comes with its own sets of barriers; establishing a virtual forum for these debates might increase efficiency and efficacy of these services. Finally, the theme or category related to the 'citizen' houses information, indicator and services that are not participatory in nature or aimed at civic engagement. These items (i.e. extreme weather services, tips on pet care, and obtaining vital records) could be seen as solitary in nature and providing no assistance to the citizen participation component of the digital city.

Schaumburg, attempts to engage citizenship (customers) as a means to demystify the governmental curtain. Towards this end, the village of Schaumburg created a custom written (written by an internal department) service request system. The village took out the barrier of having the user pick a department and/or problem area. Instead, the user has open field text boxes to describe the reason for their communication. Schaumburg creates an open narrative in service request, while limiting barriers to results.

All requests go to the universal 311 center, where staff evaluates content and sends to appropriate department. Present ongoing activities in a clear matter; goal is selfservice as citizens.

The access number on the website for use of "information, sustainability indicators and public services" reiterates citizen participation. In addition, demonstrates that both cities are on the way to the expansion of the citizen quality of life and the public managers' effectiveness.

\section{DISCUSSION AND CONCLUSION}

To provide smarter governance and city sustainability it is necessary to have useful information, indicator and adequate public services as a form of participation in the planning and sustainability management in cities.

Revista de Gestão e Secretariado-GeSec, São Paulo, v. 7, n. 2, p 55-79,mai./ago.2016. 
Innovative information technology (IT) achieves this. This trend has become essential for the contemporary city, and it requires the participation of citizens and public managers to expand urban, rural and regional development. From the point of view of the citizen, municipal planning can also promote the practice of citizenship as citizens take part in the planning, structuring, storage and release of information and indicator for their use and benefit. This is particularly true insofar as the increase in public participation-based public services is concerned. Municipal planning also allows cities to expand their communications, education and social development activities. This is becoming more urgent as a large number of cities face social, environmental, financial and political challenges to promoting effective municipal management and improved quality of life for their citizens.

The research question was answer: because it is possible to structure, store and make available information, indicator and public services for citizens and public managers, it was written in the variables to research: communicability; content; functionality; public services; and citizen participation analysis. In addition, all variables researched can contribute to the citizen quality of life and with the public managers' effectiveness, because through the "information, sustainability indicators and public services" available, decisions and actions of citizens and public managers can be more effective.

Undoubtedly, information, indicator and public services planning, like municipal strategic planning, can become an inexorable participative instrument of management for municipal government. With the right modeling, planning and availability of information, indicator and municipal services, it makes possible the breakthroughs in citizenship building within the public space, municipal democratic governability, and transparency of management and in the urban, rural and regional development of the cities. Also, the information and indicator can facilitate communications between the citizens and govern to expand credibility, trust and equality, promoting accountability, transparency, and democracy.

The objective of describing the digital cities projects in Chicago and Schaumburg has been achieved as details of the information, indicator and public services in these municipalities have been presented through their websites. Both projects covered city hall, municipal departments and other municipal entities, such as schools, health centers and citizen-oriented municipal information offices. Despite both cities, have their projects among the USA top 10.

Chicago offers its citizens 281 public services distributed in 256 subjects or themes and Schaumburg 19 public services distributed in 16 categories, subjects or themes. 
Despite numerical differences, the digital city projects are very similar. The similarities were observed in the analysis of selected criteria (communicability; content; functionality; security and privacy; public services; and citizen participation). Despite the number of information, indicator and public services offered as well as the similarities, both projects can be improved and should be further extended to citizens. Especially when thinking of the citizens with low education and minimal familiarity with the use of the internet.

Also of note are the advantages for the citizens of Chicago and Schaumburg, who have free communal access to public services on the internet as a form of participation in the society's environment and cities.

Based on number of services offered, Schaumburg provides its citizens with a great deal more services, subsumed under more concise categories or themes. This fact informs the content indicator of Schaumburg's services, in that navigation through the website is more streamlined.

Both projects resulted in benefits for the municipalities, notably modernization of municipal management activities improved access to information, indicator and public services as a result of increased internet use brought about by digital inclusion. With the use of the resources of information technology, it was observed that it is possible to integrate the citizen to the government. With this integration, it was possible to realize enhanced communications between the citizens and government, expanding the credibility, trust and equality while promoting accountability, transparency, and democracy.

Evidently, there were many difficulties throughout the elaboration of this study to describe and assess the information, indicator and public services of the digital city projects. The main limitation was the use of only the websites for research, without elaboration of services through interviews and meetings with managers and technicians of the City Hall in both cities.

These studies report the description and assessment of information, indicator and public services of two urban centers with comparable digital city projects. Such contributions are addressed to the academy, to the cities studied, and to other geographic areas. The case studies described provides a framework for further research to understand and suggest alternatives for their challenges to urban, rural and regional development, and also for entities concerned with the quality of life of citizens. This work also contributes to the establishment of analogies among the cities. 
The methodology benefits from the lack of restrictions on websites, or restrictions to information, indicator or public services of the city and of the City Hall. The main barrier to this work had to do with the research methodology itself as it reduces pertinent analyses and considerations to two cities and does not express the reality of American and Brazilian cities.

The analysis reiterates the importance of availability of information, indicator and the provision of public services to citizens through the Internet in their respective digital city projects. Information, indicator and public services allow citizens to plan and decide the most adequate use of such services. With the effective implementation of this kind of project, the role of "democratic public space", transparency, and efficiency of public services all increase. This can enhance social, urban, rural and regional development as well as the quality of citizens' lives.

\section{APPENDIX 1}

Information, indicator and public services offered by Chicago: abandoned; abandoned construction sites; abuse; accessibility; activity; adoption; advertising; alert; alley; alley light; animal; appeal; application; artist; assessment; assistance; backup; basement; benefit; bicycle; blood test; breast; brochure; building; calendar; care; career; caregiver; cart; cat; certification; check-up; Chicago; Chicago cultural center; child; citizen; city; city maintenance; city services; clean-up; clinic; code; communication; community; community services; complaint; compliment; construction; consultant; consultation; contract; contractor; corruption; counseling; crisis; cruelty; dca; damage; debris; development; disability; disabled; discrimination; district; doctor; dog; domestic; donation; drain; drivers; drug; dumping; educational resource; elderly; electrical; elevator; emergency; emergency response; engineer; environment; environmental; ethics; evaluation; event; exam; ex-offender; exposure; exterior; family; family planning; fare card; fees; filming; financial; assistance; fire; foia; food; forestry; form; garbage; grandchildren; grandparents; green; green building; gynecology; hand washing; health; health resource; health services; heat; help; hiv/aids; home visit; homeless; housing; illegal; illegal sale; impound; independent; infant; information and indicator; inspection; internship; intervention; issue; job training; kids; landfill; learning; license; light pole; liquid; local; location; maintenance; mammogram; map; mason; mbe/wbe/dbe/bepd; meals on wheels; mechanic; medical; medicine; mental health; minority; motorists; 
municipal; neighborhood; newsletter; no smoking; nutrition services; occupancy; online; park; parking; partnership; payment; pelvic; exam; permit; pet; physical; pick up; placement; planning; planting; plumbing; police; policy agenda; pothole; power; preschool; problem; procurement; program; project; property; protest; public; public health; pushcart; record; recycling; red-light; reentry; regional transit authority; registration; relief; rental; repair; report; residence; residential; resource; respite; restaurant; retail; review; rock; rodent; safety; sale; sanitary; sanitation; sanitation code; senior; services; sewer; shakman; shelter; sign; smoke; smoking; snow; sponsor; sponsorship; sports; status; sti; sti/hiv; sticker; storage tank; stray; street; street light; substance; summer job; support; tax; tax/fee/bill/ticket; taxi; testing; training; transportation; trash; tree; vacant lot; vehicle; vendor; vendor payment; venue; viaduct; violation; violence; violence prevention; waiver; wall; waste; water; weather; weeds; wellness; wheel chair; women's health; workshop; youth; zoning.

\section{ACKNOWLEDGMENTS}

CNPq-Brasil; FA-Paraná; PUCPR-PPGTU; DePaul-SPS.

\section{REFERENCES}

Atkinson, R. The digital technology revolution and the future of US cities. Journal of Urban Technology, v. 4 (1), p. 81-98, 1997.

Aurigi, A.; Graham, S. Virtual cities, social polarisation and the crisis in urban public space. Journal of Urban Technology, v. 4 (1), p. 19-52, 1997.

Barbero, J. M. La ciudad virtual: transformationes de la sensibilidad y nuevos escenarios de comunicaión. Revista de la Universidad del Valle, n. 14, Cali, 1996.

Batten, D. Networked cities: creative urban agglomerations for the 21st century. Urban Studies, v. 32 (2), p. 313-327, 1995.

Besselaar, P. V. D.; Beckers, D. Demographics and sociographics of the digital city. Available at: <http://portal.acm.org/citation.cfm?id=701393>. Accessed: Feb, 2, 2009.

Castells, M. A Sociedade em Rede. A era da Informação: economia, sociedade e cultura. 8 ed. São Paulo: Paz e Terra, 2005.

Denhardt, R.; J. Denhardt. The new public service: serving rather than steering. Public Administration Review, v. 60 (6), p. 549-559, 2000. 
Digital Communities. Digital Cities Survey. Available at: <http://www.digitalcommunities.com/survey/cities>. Accessed: Feb, 15, 2013.

Duarte, F.; Pires, H. F. Inclusión digital, tres conceptos clave: conectividad, accessibilidad, comunicabilidad. Revista Electrónica de Recursos em Internet sobre Geografía y Ciencias Sociales, v. 150 (1), p. 1-15, 2011.

Ekionea, J. B.; Fillion, G.; Koffi, V. Journal of Information \& Knowledge Management, v.11(04), p. 1-21, 2012.

England, R. E.; Pelissero, J. P.; Morgan, D. R. Managing urban America. 7th ed. Washington: CQ Press, 2012.

Firmino, R. J. Building the virtual city: the dilemmas of integrative strategies for urban and electronic spaces. Doctoral thesis, University of Newcastle, 2004.

Flores, C. C.; Rezende, D. A. Strategic digital city: techno-social network twitter as communication channel for popular participation in city comprehensive plans. Nineteenth Americas Conference on Information Systems (AMCIS), Chicago, August 15-17, 2013.

GFLDR. Global Forum on Local Development Report. Local governments and service delivery: pursuing the MDGs through local government. Kampala, Uganda, October 2010. Available at: <http://www.uncdf.org/gfld/en/index.php〉. Accessed: July, 21, 2013.

Gil, A. C. Métodos e técnicas de pesquisa social. 5. ed. São Paulo: Atlas, 1999.

Gruber, J. Public finance and public policy. 3 ed. New York: Library of Congress, 2011.

Guerreiro, E. P. Cidade digital: infoinclusão social e tecnologia em rede. São Paulo: SENAC São Paulo, 2006.

Heeks, R. Reinventing government in the information age: international practice in ITenabled public sector reform. London/New York: Routledge, 2001.

Henderson, J. C.; Venkatraman, N. Strategic alignment: leveraging information technology for transforming organizations. IBM Systems Journal, v. 32 (1), p. 4-16, 1993.

Holzer, M.; Kim, C.; Kim, S.; Melitski, J.; Rho, S. Digital government worldwide: an egovernment assessment of municipal Web sites. International Journal of Electronic Government Research, v. 1 (1), p. 1-19, 2005.

Ishida, T. Activities and technologies in digital city Kyoto. Lecture Notes in Computer Science, State-of-the-Art Survey, 3081, 2004. Available at: <http://www.digitalcity.gr.jp/DigitalCityKyoto20040601.pdf>. Accessed: May, 21, 2012.

Kroenke, D. MIS essentials. 2. ed. New Jersey: Prentice Hall, 2011.

Laudon, K. C.; Laudon, J. P. Management information systems: managing the digital firm. 12. ed. New Jersey: Prentice Hall, 2011.

Revista de Gestão e Secretariado-GeSec, São Paulo, v. 7, n. 2, p 55-79,mai./ago.2016. 
Lederer, A. L.; Mahaney, R. C. Using case tools in strategic information system planning. Information Systems Management Journal, USA, v. 13 (4), p. 47-52, Fall, 1996.

Lefebvre, H. The production of space. Oxford: Basil Blackwell, 1991.

Lemos, A. (Org.). Cibercidades II. Ciberurbe: a cidade na sociedade da informação. Rio de Janeiro: Editora E-Papers, 2005.

Lévy, P. Cibercultura. São Paulo: Editora 34, 1999.

Meirelles, H. L. Direito administrativo brasileiro. 39 ed. São Paulo: Malheiros, 2013.

Mendes, L. S.; Bottoli, M. L.; Breda, G. D. Digital cities and open MANs: a new communications paradigm. IEEE Latin-American Conference on Communications, v. 8 (4), p. $1-8,2010$.

Middleton, M. R. Approaches to evaluation of websites for public sector services. In Kommers, Piet, Eds. Proceedings IADIS Conference on e-Society, pp. 279-284, Lisbon, Portugal, 2007.

Mossberger, K. et al. Digital citizenship: the internet, society, and participation. Cambridge, Massachusetts: MIT Press, 2008.

Nachmias, D.; Nachmias, C. Research methods in the social sciences. 6. ed. New York: Worth Publishers, 2006.

Nolan, R. L. Note on information technology and strategy. Boston: Harvard Business School, 1993.

O’Brien, J. A.; Marakas, G. M. Introduction to Information Systems. 15 ed. Columbus: McGraw-Hill, 2011.

Rezende, D. A. Planejamento de estratégias e informações municipais para cidade digital: guia para projetos em prefeituras e organizações públicas. São Paulo: Atlas, 2012.

Rezende, D. A.; Madeira, G. S.; Mendes, L. S.; Breda, G. D.; Zarpelão, B. B.; Figueiredo, F. C. Information And Telecommunications Project for a Digital City: A Brazilian case study. Telematics and Informatics, v. 31 (1), p 98-114, 2014.

Rezende, D. A.; Procopiuck, M.; Figueiredo, F. C. Public Policy and a Strategic Digital City Project: a case study of the Brazilian Municipality of Vinhedo. The Journal of Urban Technology, v.22, on-line p. 1-21, 2015.

Roesch, S. M. A. Projeto de estágio e de pesquisa em administração: guia para estágios, trabalhos de conclusão, dissertação e estudos de caso. 2. ed. São Paulo: Atlas, 1999.

Shiode, N. Urban planning, information technology, and cyberspace. Journal of Urban Technology, v. 7 (2), p. 105-126, 2000.

Revista de Gestão e Secretariado-GeSec, São Paulo, v. 7, n. 2, p 55-79,mai./ago.2016. 
Skelcher, C. Improving the quality of local Public services. The Service Industries Journal, v. 12 (4), p. 463-477, Oct 1992.

Stair, R. M. Principles of information systems: a managerial approach. 8 ed. Boston: Course Technology, 2007.

Townsend, A. Wired/unwired: the urban geography of digital networks. Urban Studies and Planning, Massachusetts Institute of Technology. Cambridge: 206, 2003.

Turban, E.; Mclean, E.; Wetherbe, J. Information technology for management: improving quality and productivity. New York: John Wiley and Sons, 1996.

Ward, J.; Peppard, J. Strategic planning for information systems. New York: John Wiley \& Sons, 2002.

Weitzen, H. S. O poder da informação: como transformar a informação que você domina em um negócio lucrativo. São Paulo: Makron Books, 1991.

Yin, R. K. Case study research: design and methods. 4 ed. London: Sage Publications Inc., USA, 2008. 